\title{
A Geological Itinerary Through the Southern Apennine Thrust Belt (Basilicata-Southern Italy)
}

\author{
Mario Bentivenga ${ }^{1}$ - Giuseppe Palladino $^{2}$ - Giacomo Prosser $^{1}$ • Paola Guglielmi ${ }^{1}$. \\ Francesco Geremia ${ }^{3}$ • Angela Laviano ${ }^{1}$
}

Received: 30 March 2015 / Accepted: 19 November 2015 / Published online: 10 December 2015

(C) The Author(s) 2015. This article is published with open access at Springerlink.com

\begin{abstract}
The proposed geological itinerary connects a series of impressive outcrops distributed between the front and the inner portion of the Southern Apennine thrust belt. It offers the opportunity to visit some of the most interesting and bestexposed Southern Apennine geosites, inserted within landscapes typical of the different sectors of the thrust belt, in order to illustrate its geological evolution. The itinerary has been designed in such a way as to intersect different stacked tectonic units and a great variety of sedimentary successions whose age ranges from Triassic to Pleistocene. Each of the chosen geosite contains multidisciplinary geological information that may be of interest for researchers, but may be also appreciated by a general public interested in geology. In particular, the stratigraphy, the structural geology and the geomorphology are the most recurrently treated topics. Most of these outcrops extend for many hundreds or thousands of metres and include villages or mountain reliefs. Therefore, every single site can be considered as an areal geosite containing particular geological features. However, the largest geosite can also be observed in a panoramic view from suitable locations. Thus, each of these sites provides different evidence and when combined together provides an opportunity to understand the complex geological history of the Southern Apennines. The motivation for establishing this itinerary mostly resides in the great
\end{abstract}

Giuseppe Palladino

giuseppe.palladino@abdn.ac.uk

1 Dipartimento di Scienze, Università degli Studi della Basilicata, Via Ateneo Lucano, 10-85100 Potenza, Italy

2 King's College, University Aberdeen, Aberdeen, Scotland, UK

3 ProGeo and Sigea Executive Commitee, Via Tevere 11, San Gregorio di Catania 95027, CT, Italy scientific interest of the chosen outcrops; this will hopefully facilitate their conservation and the development of geotourism.

Keywords Geological itinerary $\cdot$ Geosites $\cdot$ Southern Apennines $\cdot$ Basilicata $\cdot$ Italy

\section{Introduction}

In the Southern Apennine thrust belt, key geological areas can be opportunely connected together in order to illustrate the tectono-sedimentary history of the chain (Fig. 1). In the proposed itinerary, six geosites (sensu Wimbledon et al. 1995; Wimbledon 1996a, b). distributed between the front (Craco area) and inner portions (Agri valley) of the Southern Apennines, have been selected along a $150-\mathrm{km}$ long route. These outcrops allow the observation of the main tectonic units, structures, sedimentary successions and morphological features characterizing the Southern Apennine thrust belt. They have been selected by taking into account some fundamental features such as geological relevance, good quality of the exposure and easy accessibility.

The itinerary starts from the frontal sector of the chain, where contractional structures mostly involve clastic deposits of Pliocene to Pleistocene age and terminates in the internal sector, characterized by exposures of Mesozoic rocks affected by both contractional and extensional deformations. Consequently, the arrangement of the stops simulates a time travel, from the youngest sector characterized by simple deformation features to the oldest portion, where different tectonic events are superposed through time.

The first stop is located at Craco, a very impressive ghost village, suddenly abandoned by the population as a consequence of the reactivation of a large landslide during the 


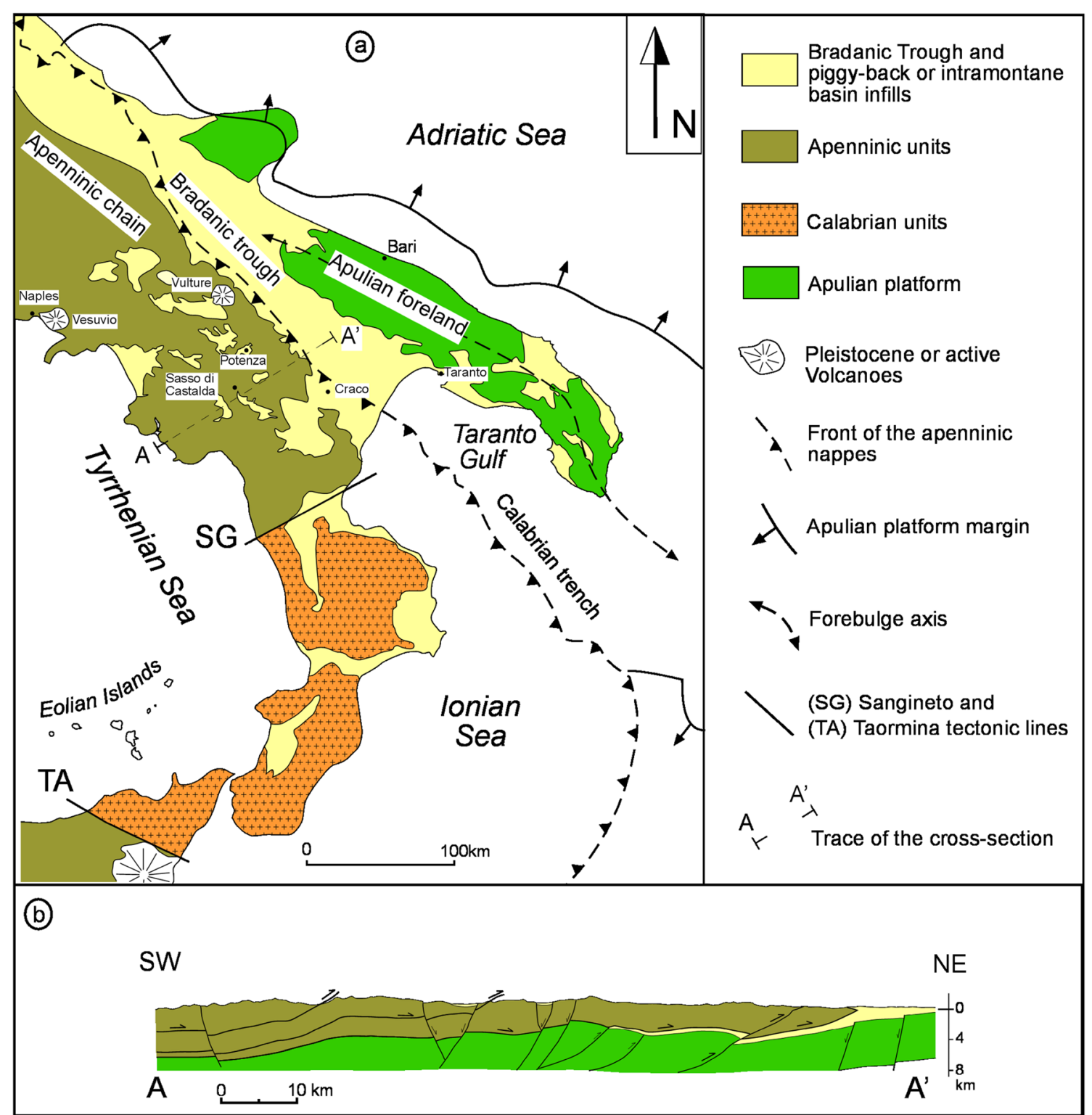

Fig. 1 a Geological sketch map of the Southern Apennines and surrounding areas; b geological cross-section (Bentivenga et al. 2004, modified)

catastrophic Irpinia earthquake on 23 November 1980. The older portion of the village lies above a steeply dipping Pliocene conglomerate succession, which is part of the Southern Apennines frontal thrusts system facing the Bradanic Trough (the emerged Southern Apennine foredeep). Because of the involvement of Pliocene to Late Pleistocene deposits, the Craco village is a key area for the observation of the most recent contractional structures of the Southern Apennine thrust belt. The second stop is represented by the Alianello anticline, a $\mathrm{N} 140^{\circ}-150^{\circ}$ trending growth fold involving the Pleistocene coarse-grained deposits, which filled the Sant'Arcangelo Basin. The occurrence of this growth structure is fundamental for constraining the latest contractional stages in the chain. The third stop represents the badlands area of Aliano. This locality offers one of the most striking landscapes of the Southern Apennine thrust belt and is provided by the exposure of the Early Pleistocene Sant'Arcangelo Basin clays. The fourth stop, located in the internal sector of the chain, is represented by the 'Il Monte', a carbonate relief showing a very rich Cretaceous fossil macrofauna (essentially rudists and gastropods) and clearly evident bounding tectonic structures.

The fifth stop is represented by the Volturino structure, a spectacular, anticline-syncline pair involving the thinly bedded Mesozoic deposits of the Lagonegro Basin. Here, a great variety of parasitic folds, connected to the major structure, are magnificently exposed at different scales. The sixth stop, showing by the Monte Lama-Serra di Calvello structure, consists of a prominent $\mathrm{N}$-trending faulted box fold, in which it is possible to observe the entire Mesozoic Lagonegro succession 
and some peculiar and geomorphological features such as the M-shaped geometry made by the beds at the core of the fold and pentagonal facets considered to represent remarkable example of flat irons. The seventh stop is represented by the structures cropping out at Sasso di Castalda village. Here, the complete Mesozoic succession of the Lagonegro Basin, deformed by peculiar tectonic structures, is spectacularly exposed along the La Manca gorge.

The proposed itinerary has been established due to a desire to present the peculiarities and possible fragilities of the described geosites. This should serve to encourage land managers to develop appropriate measures for the geoconservation of the sites of geological interest. This itinerary was successfully tested for the first time during the 7th International Symposium ProGEO on the 'Conservation of the Geological Heritage' that was held at Bari (Italy) on the 24th-28th September 2012. About 40 participants, coming from different parts of Europe, took part in the post-symposium field trip which was organized in collaboration with the Department of Science of the University of Basilicata and SIGEA Basilicata.

\section{Geological Setting}

The Southern Apennines represent a NW-SE-oriented segment of an arc-shaped thrust belt extending from Northern Africa to the Alps and including the Magrebian area in Sicily, the Calabria arc and the central and Northern Apennines (see Gueguen et al. 1998, for a regional scheme of the Mediterranean area). The considered sector is bounded by major transversal tectonic lineaments, represented by the Sangineto-Pollino faults to the south and the Tremiti-Ofanto faults to the north (Fig. 1).

According to current models (Malinverno and Ryan 1986; Doglioni 1991; Gueguen et al. 1998; Rosenbaum and Lister 2004; Mattei et al. 2007; Patacca and Scandone 2007). the Southern Apennine arc originated above the NW dipping subduction of the African palaeomargin, represented by the Adria-Apulian element, beneath the European margin. The Tyrrhenian Sea opened as a backarc basin starting from the Early Miocene, due to the south-eastwards retreat of the subduction hinge. Backarc opening was accommodated by a series of extensional faults, whose activity was synchronous with thrusts in the frontal sector of the Apennine chain (Kastens et al. 1988). during a time span from the Late Miocene to the Pleistocene. Therefore, contractional and extensional tectonics migrated progressively towards the E-SE, due to the displacement of the subduction hinge in the same direction (Doglioni 1991).

The geological history of the Southern Apennine thrust belt is connected with the complex geodynamic evolution of the Mediterranean Sea, reflecting the interaction between the African and the European plates. During the TriassicJurassic time, the Africa-Europe continental separation led to the opening of the so-called Ligurian-Piedmont Ocean that is considered the western branch of the Alpine Tethys Ocean (Stampfli et al. 2002). In the same time interval, the northern margin of the African plate was characterized by a series of fault-bounded structural highs and lows, which favoured the formation of a series of platforms and basins. The main palaeodomains were, from $\mathrm{W}$ to the $\mathrm{E}$, the Apennine or Campano-Lucana Platform, the Lagonegro Basin and the Apulian Platform. The Mesozoic paleogeographic domains have been progressively inverted when westward subduction of the Ligurian-Piedmont Ocean was activated during Late Cretaceous-Eocene times (Knott 1994; Cello and Mazzoli 1999). This led to the formation of an accretionary wedge, which collided with the Northern African palaeomargin during the Early Miocene.

A stack of tectonic units derived from the Mesozoic palaeogeographic domains dominates the present-day structure of the Southern Apennines (Fig. 1b). From the top to the bottom the units are (i) the Liguride and Sicilide complexes, derived from the Ligurian-Piedmont Ocean and the ocean to continent transition and (ii) units derived from inversion of the northern African palaeomargin, namely, the Campano-Lucana Platform, the Lagonegro Basin and the Apulian Platform. The lithologies of the main tectonic units are briefly summarized below.

The Liguride Complex (Ogniben 1969) consists of a deepwater sedimentary succession scraped off from the subducted crust of the Ligurian-Piedmont Ocean. According to the schemes proposed by several authors (Monaco and Tortorici 1995; Invernizzi et al. 2008; Cavalcante et al. 2012). it is possible to distinguish a structurally lower non-metamorphic unit, which includes pillow basalts overlain by Upper Jurassic radiolarites, shales and quartzarenites (Timpa delle Murge Fm), black shales (Crete Nere Fm) and mixed calcareoussiliciclastic turbidites (Saraceno Fm). The Frido Unit, composed of slightly metamorphosed sedimentary rocks, including lenticular bodies of mafic and ultramafic rocks, occurs above. The upper part is made up by a tectonic mélange, where kilometer-scale blocks of serpentinites, granulites, amphibolites and granitoids are dispersed within a metapelite matrix. Units whose provenance was closer to the northern palaeomargin of the African plate have been referred to as the Sicilide Complex (Ogniben 1969). These comprise a Cretaceous-Miocene succession which includes varicoloured clay and marly limestone.

The succession of the Campano-Lucana Platform consists of a thick pile of shallow-water Meso-Cenozoic carbonates, formed in peritidal to lagoonal environments (Alburno-Cervati-Pollino Unit), passing laterally to the adjacent marine basins through gently dipping slopes characterized by bioclastic and detrital resediments (Capri-Bulgheria and Monti della Maddalena Units; D’Argenio et al. 1973; Scandone and Bonardi 1968; 
Marsella and Pappone 1987; Carannante et al. 1999; Pescatore et al. 1999; Iannace et al. 2005).

The succession of the Lagonegro Basin consists of MesoCenozoic shallow-water to pelagic sediments, recording a progressive subsidence below the CCD. These are represented initially by shallow-water siliciclastic deposits (Monte Facito Formation), followed upward by pelagic cherty limestones (Calcari con Selce Formation), cherts and radiolarites (Scisti Silicei Formation) and finally by silicified marls and clays (Galestri Formation) ( Scandone 1967).

The Apulian Platform succession consists of a thick pile of Meso-Cenozoic shallow-water carbonates stratigraphically overlying a Permian-Triassic evaporite-siliciclastic succession (Crescenti 1975; Mostardini and Merlini 1986; Ricchetti et al. 1988). The entire succession has been drilled in the Puglia 1 exploration well and partially crops out in the Monte Alpi tectonic window (Van Dijk et al. 2000).

The inversion of the relative motion between the African and the European plates led to convergence in the ApennineAlpine system from Cretaceous times. As a consequence, contractional deformation involved the southern sector of the Ligurian-Piedmont Ocean and, in turn, the northern margin of the African plate during the Oligocene time. As the orogenic front moved towards the foreland, the palaeodomains described above experienced contractional deformation with the development of a series of E-NE-vergent low-angle thrusts and NW-SE trending folds. During contractional stages, an initial series of thrust-sheet top deposits were originated and later involved in mountain building processes. Remains of these basins, progressively younging towards the foreland, represent a useful geological marker for providing age constraints for the tectonic evolution of the Southern Apennines.

Deposits of the older thrust-sheet 'top' deposits are represented by the Lower Miocene Albidona Formation. According to Bonardi et al. (1985) and Lentini et al. (1987). these deposits seal the tectonic contact between the Ligurian and the Campano-Lucana Platform units as well as the contact between the Campano-Lucana Platform and the Lagonegro units. The Middle-Upper Miocene thrust-sheet top deposits, generally referred to as the Irpinian Basin (Pescatore 1988). are represented by the deep-sea turbidites of the Serra Palazzo, Gorgoglione, Castelvetere and Faeto formations. Sedimentation of the Irpinian units followed the tectonic closure of the Lagonegro Basin.

The renewed contractional tectonics during the MessinianPleistocene time caused the deformation of Irpinian Basin and the north-eastward translation of Southern Apennines accretionary wedge on the Apulian Platform. During the PlioPleistocene, sheet top deposits unconformably overlie the Southern Apennine allochthonous sheets filling the major structural depressions (Ofanto, Sant'Arcangelo, Potenza and Anzi-Calvello basins). The Sant'Arcangelo Basin (Caldara et al. 1988; Hippolyte et al. 1994) is defined as a triangular- shaped basin, bounded by oppositely verging thrusts (Benvenuti et al. 2006). Following Pieri et al. (1994). the basin infill, up to $5 \mathrm{~km}$ in thickness, is made up of four depositional sequences, bounded by major basin-wide unconformities, spanning from the Late Pliocene to the Middle Pleistocene. Every sequence is composed of different lithofacies assemblages recording cyclic activation of fluvial, deltaic, shallow marine (Caliandro, Agri and Sauro cycles) and lacustrine (San Lorenzo Cycle) environments, with evidence of synsedimentary tectonics (i.e. growth faults or folds).

The frontal portion of the Southern Apennines consists of imbricate thrust sheets, made up essentially of Irpinian and Lagonegro units that tectonically overlie the Pliocene-Early Pleistocene foredeep deposits of the Bradanic Trough (Piedilato and Prosser 2005; Palladino 2011). The allochtonous units are thrust over the Plio-Pleistocene sediments along a shallow-dipping surface. In turn, the imbricate thrust sheet is unconformably covered by Early-Middle Pleistocene foredeep deposits. The structural setting of this portion of the chain may be studied using surface data integrated by subsurface information, because of the presence of a series of wells for hydrocarbon exploration. Data from seismic lines and oil wells have been used to obtain a detailed map of the top of the buried Apulian carbonates (Crescenti 1975; Balduzzi et al. 1982; Sella et al. 1988; Bigi et al. 1991; Nicolai and Gambini 2007).

Geological data suggest that when the Southern Apennine nappes overthrusted the Apulian carbonates, the foreland area underwent a progressive flexure that was largely accommodated by the development of normal faults, roughly dipping towards the W-SW. The resulting accommodation space was filled up with the siliciclastic deposits pertaining to the Bradano foredeep (Patacca and Scandone 2001). The progressive subsidence affecting the Apulian plate, well imaged by published seismic lines, is marked by an evident onlap contact of the Pliocene siliciclastic deposits of the Bradano foredeep onto the Meso-Cenozoic carbonates. Starting from the Early Pleistocene, the buried Apulian carbonates were involved in thrusting, through the activation of a series of medium to highangle, out-of-sequence, reverse faults, giving rise to a series of structural highs. Actually, some structural highs of the Apulian carbonates are the main target for hydrocarbon exploration in Southern Italy. They commonly show a steep frontal ramp usually connected to oblique lateral ramps characterized by a significant strike-slip component. The main example is the Stigliano ramp (Catalano et al. 1993; Monaco et al. 1998; Patacca and Scandone 2001; Lentini et al. 2002). considered as a prominent Middle Pleistocene out-of-sequence thrust, bounded southwards by the left-lateral Scorciabuoi fault (Pieri et al. 1997; Bonini and Sani 2000). The latter structure produced kilometer-scale left-lateral displacements during the Early-Middle Pleistocene times at the northern margin of the Pliocene-Pleistocene Sant'Arcangelo Basin. 


\section{The Itinerary}

The itinerary develops for about $120 \mathrm{~km}$, and the sites of geological interest are all easily accessible (Fig. 2). A full day is needed to follow the route and to observe all the stops. All the geosites reported in this paper are easy to access for anyone who would wish to travel the entire itinerary. These are located nearby the main state, provincial and/or municipal roads that are used in the itinerary. Roads are generally in good conditions and can be travelled by car. A short walk may be necessary for reaching the stops and the best viewpoints.

The first geosite (village of Craco) falls in the Basento river valley that is reached after about $20 \mathrm{~km}$ starting from the highway exit to Pisticci Scalo (Fig. 2). A short journey is needed to arrive at the Agri valley, where the badlands area of the Aliano and the Alianello anticline can be observed. Continuing along the S.S. n. 598, for about $40 \mathrm{~km}$, a good viewpoint for 'Il Monte' can be reached. In order to observe the folds of Monte Volturino, a further $15 \mathrm{~km}$ are needed. The Monte Lama and Serra di Calvello can be reached after a 20$\mathrm{km}$ long journey along the S.S. n. 598. A further $25 \mathrm{~km}$ is needed to arrive at the last geosite (Sasso di Castalda) and thus at the end of the itinerary.

\section{Stop 1-the Geology of the Craco Village Area}

The Craco area displays some of the best outcrops within the frontal part of the Southern Apennines (Fig. 3); therefore, it is a key area for interpreting the recent evolution of the thrust belt. An additional reason for the stop is the impressive morphology of the steeply dipping conglomerate layers where the abandoned Craco village is located (Fig. 4). A detailed description of the geology of the Craco area can be found in Bentivenga et al. (2005). In this section, we provide a comprehensive summary of the geological information to highlight the significance of the Craco area for the understanding of the Apennine belt.

The outcropping lithologies consist of strongly deformed pre-Pliocene allochtonous units unconformably covered by Pliocene thrust top deposits (Ogniben 1969; Lentini 1979; Lazzari and Lentini 1980; Carbone et al. 1991; Patacca and Scandone 2001) (Fig. 3). The foredeep succession crops out extensively east of the Craco area, along the Salandrella River valley.

The allochtonous units are mostly composed of strongly tectonised varicoloured clay of Cretaceous-Oligocene age (the so-called 'Argille Variegate' or 'Argille Varicolori', see Ogniben 1969; Lentini 1979; Pescatore 1988; Carbone et al. 1991). In this area, the varicoloured clay can be considered to be a tectonic mélange (Casero et al. 1988; Roure et al. 1991) that includes disrupted beds of calcarenite, calcilutite, marl, carbonate platform limestone and quartz-arenite.

The Pliocene deposits can be divided into two cycles separated by an obvious unconformity (Lazzari and Lentini 1980; Carbone et al. 1991). The older cycle is generally made up of conglomerate and sandstone, bioclastic sand and minor marly clay. The marly clays outcropping in the upper part of the succession have an Early Pliocene age and are referred to the G. puncticulata-G. margaritae Zone (Iaccarino and Salvatorini 1982, modified in Foresi et al. 2000-2001). The cumulative thickness of the first cycle can be estimated to be approximately $160 \mathrm{~m}$.

The younger cycle is sometimes marked at the base by a sandstone interval, which grades upwards to clays with intervening sand levels (Craco clays according to Patacca and Scandone 2001). A remarkable feature of the second cycle is the presence of tuff levels, which are useful marker beds in the

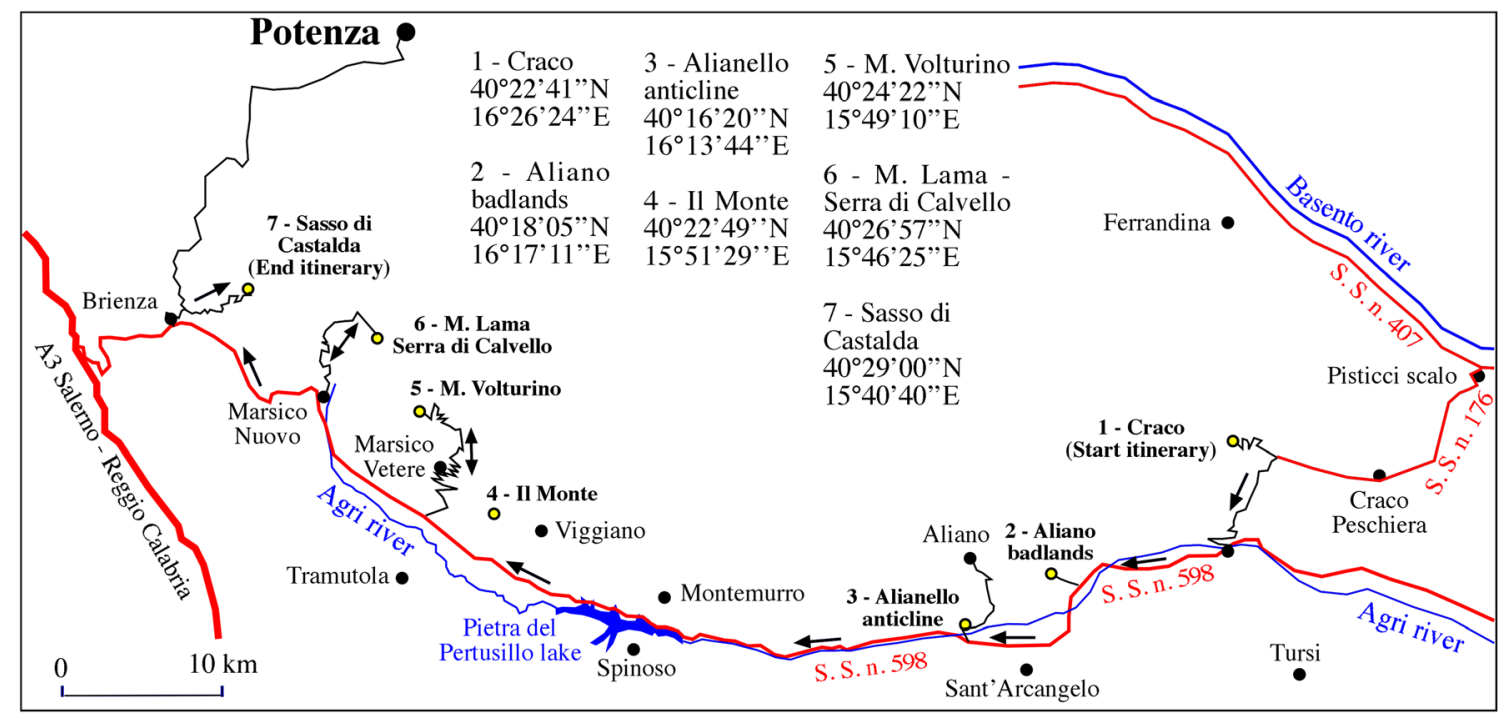

Fig. 2 Schematic map showing the suggested geological itinerary 

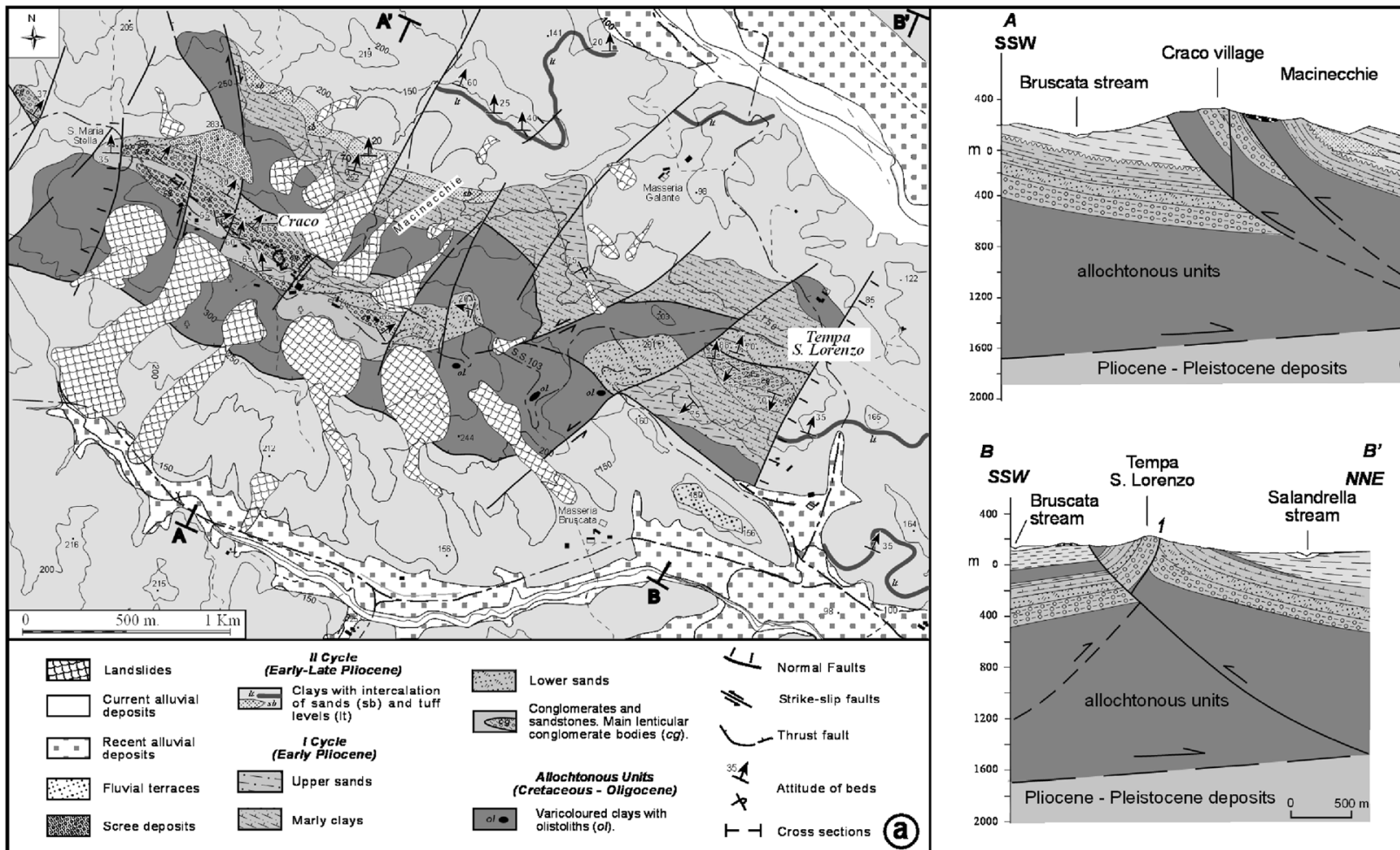

Fig. 3 a Geological map of the Craco area; (b) geological cross-sections showing the most representative structures recognized in the Craco area (Bentivenga et al. 2005, modified)

monotonous clayey succession. The thickness of the second cycle ranges between 500 and $600 \mathrm{~m}$. At the base of the second cycle, near the sandy interval, Early Pliocene ages (G. puncticulata-G. margaritae Zone) have been obtained. The upper part of the succession is younger (Late Pliocene) and can be related to the G. aemiliana Zone in the western side of the Craco hill, whereas near Macinecchie, it has been referred to the G. inflata Zone. These data are consistent with

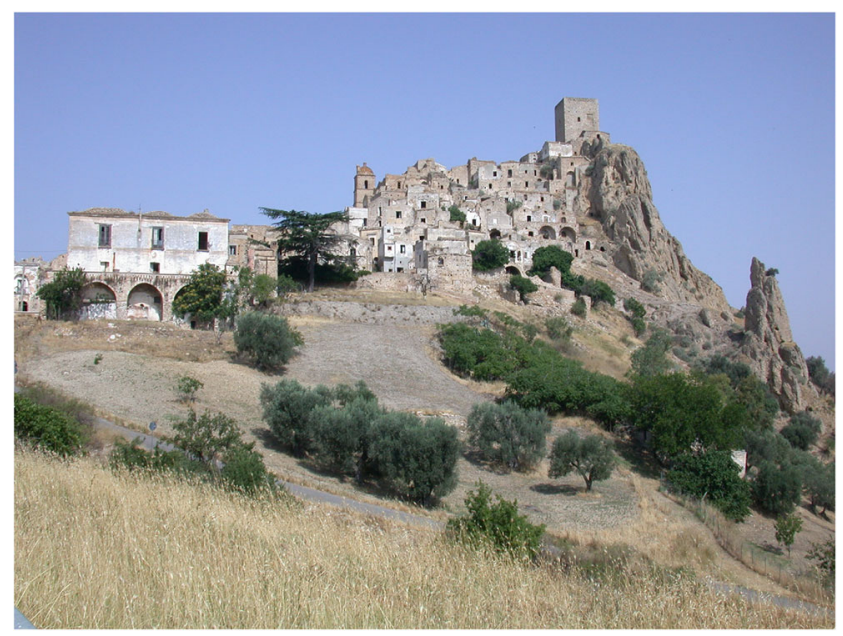

Fig. 4 Panoramic view of the Craco village from the south. The old guard tower and part of the village are located at the top of steeply inclined Pliocene conglomerates the earlier findings by Bigazzi and Bonadonna (1988). which reported Late Pliocene ages $(2.93 \pm 27-2,60 \pm 26 \mathrm{Ma})$ using fission track method on glass fragments from a tuff layer sampled in the nearby Tempa Petrolla area. A younger age (2.24 \pm 0.06$)$, corresponding to the Gelasian, has been obtained by Ar-Ar radiometric method on Amphibole from a tuff level exposed near Craco (Prosser et al. 2008).

Detailed geological mapping (Fig. 3a) shows that the Craco area is characterized by laterally discontinuous contractional structures that include thrusts, steeply dipping monoclines, backthrusts and non-cylindrical folds. Steeply dipping faults, striking N-S to N50E, offset the contractional structures. The whole area can be divided into two domains characterized by different tectonic features, portrayed by the two cross-sections of Fig. 3b. In the northwestern part of the area (corresponding to Craco village), the two Pliocene cycles, together with the varicoloured clay, are arranged into a NE-dipping monocline striking almost parallel to the buried front of the Apennine chain (NW-SE). This structure is responsible for the presence of steeply dipping layers, formed by conglomerates of the first Pliocene cycle, at the base of the Craco village. In the southeastern part of the area, the deposits are involved in an anticline (Tempa S. Lorenzo) (Fig. 3).

Two belts of varicoloured clay, outcropping along the eastern and western slopes of the Craco hill, are related to the presence of two backthrusts. These structures are developed within a triangle zone at the front of the Southern Apennines 
(Fig. 3a, b). The southwestern backthrust dips of about $60^{\circ}$ to the NE and emplaces the varicoloured clay over the upper Pliocene clays of the second cycle (Figs. 3a, b). The northeastern backthrust carries in the hanging wall the whole Pliocene succession, with a well-exposed contact between the first and the second cycles. This contact is characterized by the onlap of the basal sands of the second cycle over the bioclastic sands of the first cycle.

Emplacement of the allochtonous units generated uplift and tilting towards the NE of the Pliocene succession. It can be observed that units of the first cycle (Early Pliocene) are steeper than units of the second cycle (i.e., Early to Late Pliocene). This suggests that active thrust propagation started at least during the Early Pliocene in this area of the Southern Apennines. Contractional deformation continued also during and after the Late Pliocene, as suggested by dips of $25-30^{\circ}$ towards the NNE in the clays of the second cycle.

Craco village, which has been abandoned since 1980, now has several secured medieval buildings and a surveillance system has set up. In addition, because of this interesting urban area and its particular morphological configuration, Craco has gradually become a tourist destination and has been chosen as a location for many remarkable films.

\section{Stop 2-the Aliano Badlands}

The 'badlands' area of Aliano are considered to be one of the most striking landscapes that it is possible to observe in the Southern Apennine thrust belt in localities characterized by wide exposures of Plio-Pleistocene marine clays ('Argille grigio-azzurre' and Subappennine clay formations) (Fig. 5). This lithology is found in the Sant'Arcangelo thrust-sheet top basin and in the Bradanic trough.
'Badlands', the Italian term of which is 'calanchi', are defined as a form of rapid and severe linear erosion acting in semiarid climates. They are usually characterized by deeply incised, transversally V-shaped gullies, separated by steeply inclined, thin ridges (Del Prete et al. 1994) (Fig. 6). The 'badland' erosion is considered the main cause of soil degradation leading to non-compensated continuous removal of productive soils and, consequently, to desertification (Piccarreta et al., 2006a, b Piccarreta et al. 2012). The 'badland' morphology affects about one third of the territory of Basilicata and occupies most of the hilly areas of the Ionic coast inland (Del Prete et al. 1994).

A series of converging geological and climatic factors contribute to the development of 'badlands'. The fundamental geological condition is the grain size of the silty clays that crop out in the areas where the 'badlands' are developed.

In the Aliano area, this condition is satisfied by the widespread occurrence of the clayey Argille grigio-azzurre Formation. Bed attitudes are also considered to be an important factor for badland development. In the Aliano area, the 'Argille grigio-azzurre' clay is exposed in a gently NEdipping monocline, probably connected to contractional tectonics of Pliocene-Pleistocene age (Fig. 6). Commonly, when affected by erosion, monoclines assume a typical flat iron geometry. In the Aliano monocline, 'badlands' develop always on the S-SW-facing, steeper slopes. The maintenance of the characteristic concave topographic profile is guaranteed by the local occurrence of conglomerate bodies capping the Argille grigio-azzurre clays or by vegetation (often represented by Pistacia lentiscus, a characteristic plant of the 'macchia mediterranea'; Bentivenga and Fascetti 1999). Along strike, 'badlands' can form a series of well-developed fronts that can be followed for many tens of metres. 'Badland' fronts show average dip angles comprised between $35^{\circ}$ and $45^{\circ}$.

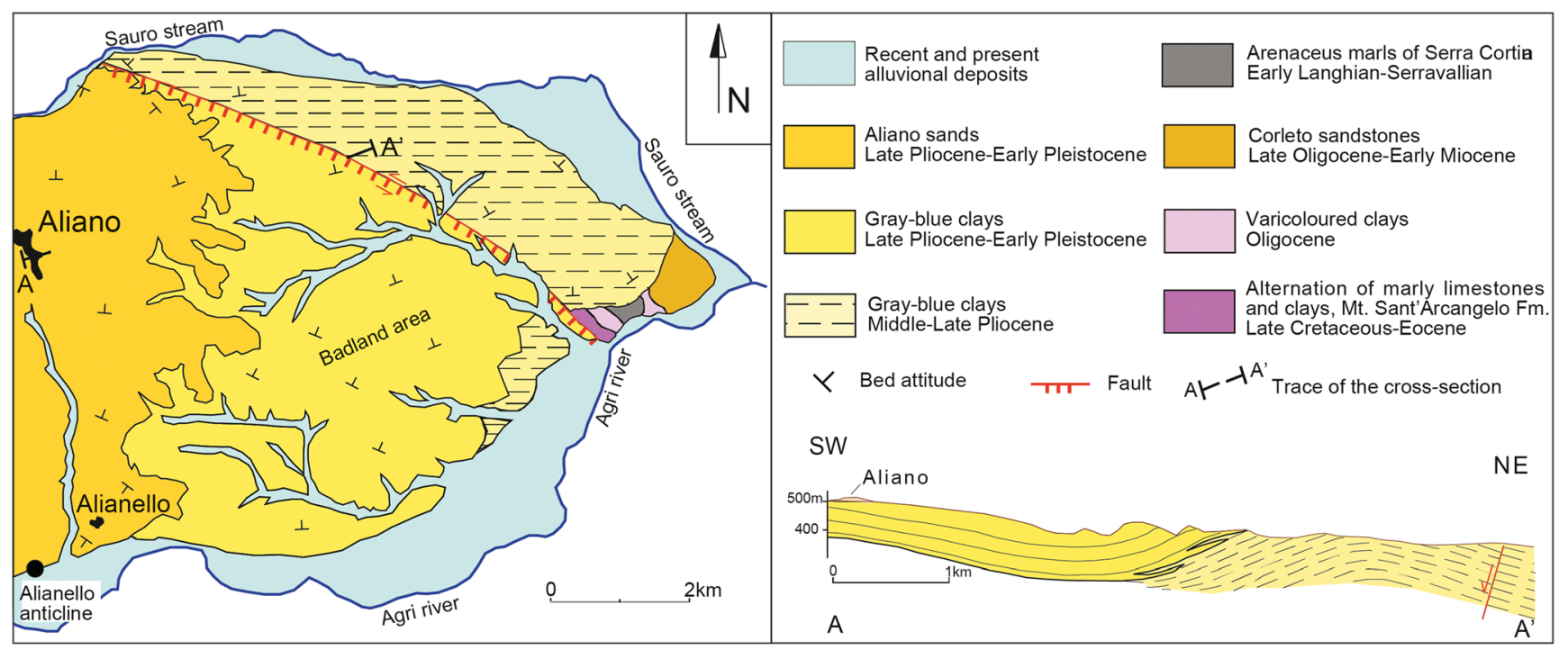

Fig. 5 Geological map of the Aliano area 
Fig. 6 Panoramic view of the Aliano badlands

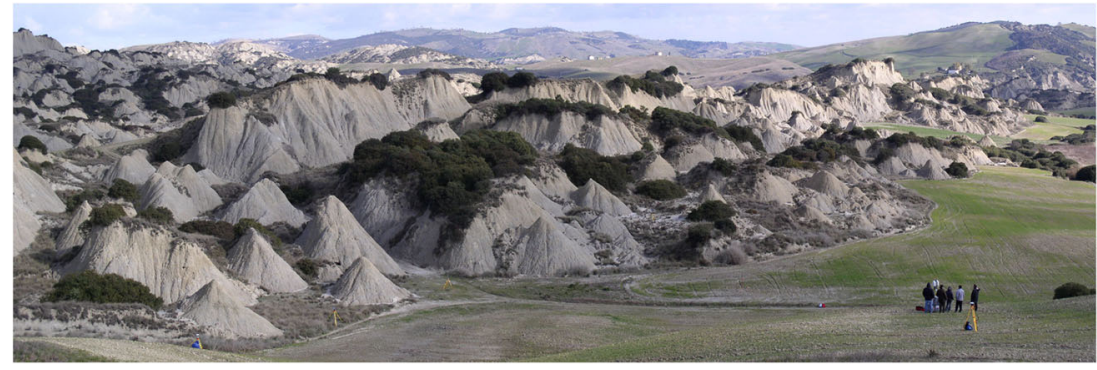

Climate factors play a fundamental role in the development of areas affected by 'badlands' erosion. Elevations in the Aliano area are between 163 and $395 \mathrm{~m}$ a.s.l. Climate studies indicate that this area is characterized by a dry period from middle May to late September. The average annual temperature is equal to $14.2^{\circ} \mathrm{C}$, and for 8 months at a year, it is constantly above $10{ }^{\circ} \mathrm{C}$. During the dry periods, this value ranges from $21.6^{\circ}$ to $24.6^{\circ} \mathrm{C}$. The average annual precipitation amounts to $723 \mathrm{~mm}$.

According to these data, the climate of Aliano 'badland' area is typically Mediterranean. The prolonged sun exposure of S-SW-oriented 'badland' fronts, which dries the clays resulting in a network of cracks, combined with rain splash and water circulation, creates an effective erosive action (Piccarreta et al. 2006a, b). In addition, during a rainstorm period, the kinetic energy of raindrops is considered to be an additional factor in removing the clayey soil. Often, along the front, the most superficial and altered soil portion (which is around $60-\mathrm{cm}$ thick) is subject to landslides during short but intense rainy events. The effect of rain splash is also testified to at a centimetre scale by the presence of small earth pyramids having their top protected by fragments of fossils and small pebbles, or by 'popcorn' structures. Relics of 'badlands' are represented by the so-called 'biancane' that are isolated, small-scale rounded hills, completely separated from the active front through gullies and pediment deposits. A direct correlation between the degree of maturity of 'biancane' and morphological parameters, as well as size and shape, has been found (Del Prete et al. 1994). Finally, areas having a typical hummocky shape ('aree mammellonari' in Italian literature) show intermediate morphologies between 'badland' and 'biancane'.

The different badland morphologies, which characterize the Aliano area, are threatened by inappropriate agricultural farming. To ensure the conservation of the badland area, it is necessary to implement strategies which deter farmers from using inappropriate agriculture practices. Since 1988, however, Aliano has been the setting for the 'Carlo Levi' Literary Park, which is an effective link between literature and territory. The initiatives of the park aim to recover and celebrate the identity of the territory, the culture, the history and the local traditions. The park is dedicated to Carlo Levi, one of the most important novelists of the twentieth century.

\section{Stop 3-the Alianello Anticline}

The Alianello anticline is a relatively recent tectonic structure since and involves the Pleistocene coarse-grained deposits filling the Sant'Arcangelo Basin (Fig. 5). The anticline shows a $\mathrm{N} 140^{\circ}-150^{\circ}$ axial trend, an obvious asymmetry and marked lateral thickness variations of the conglomerate-sandy strata forming the limbs (Fig. 7). The fold trend is in good agreement with the NE-SW shortening direction recognized across the entire Southern Apennines thrust belt. The clear fold asymmetry has been related to a SW-directed blind backthrust linked to the development of buried out-of-sequence structures. Therefore, the Alianello anticline is considered to be a fault propagation fold (Bonini and Sani 2000). The asymmetry is displayed by a steeply dipping forelimb and a gently dipping backlimb (Fig. 7).

The lateral thickness variation of the conglomerate-sandy units forming the limbs of the Alianello fold is considered as a clear evidence of contractional synsedimentary tectonics acting during the Pleistocene time (Pieri et al. 1994). In particular, this can be observed in the backlimb, where the progressive thickness increase of the beds, moving away from the fold crest, is clearly related to the growth of the Alianello anticline. In fact, the progressive uplift of the structure during blind thrusting caused the progressive steepening of the backlimb with a consequent increase in the accommodation space. Above the fold, the Sant'Arcangelo Basin deposits assume a wedge-shaped geometry. Pieri et al. (1994) suggested that the growth of the Alianello fault propagation fold during the Early and Mid Pleistocene (largely Gephyrocapsa to P. lacunosa zones) split the basin into two parts: in the northeastern part, marine sedimentation continued until the middle Pleistocene (Sauro Cycle), whereas in the southwestern part, a lacustrine system developed (San Lorenzo Cycle). The syntectonic sedimentation during the Alianello anticline's growth is also documented by the progressive unconformity developed by the onlapping lacustrine deposits onto the southwestern fold limb.

\section{Stop 4-Il Monte}

'Il Monte' near Viggiano is a mountain relief of JurassicCretaceous platform carbonates located on the northeastern 


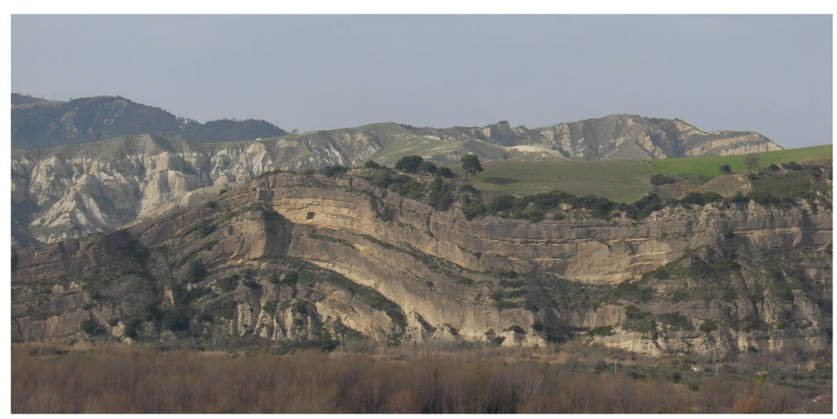

Fig. 7 Panoramic view of the Alianello anticline from the southwest. Note the thickness increase of the strata moving towards the right

side of the Agri valley (Fig. 8). In particular, its southern sector and its summit are very suitable for observing Cretaceous fossils. Platform carbonates at 'Il Monte' can be referred to the palaeogeographic domain of the Apennine Platform (D’Argenio et al. 1973; Menardi Noguera and Rea 2000).
The limestone block is bounded by important transcurrent and extensional faults (Fig. 8). The activation of strike-slip and normal faults, displaying NW-SE and NE-SW orientation, in the Late Pliocene to the Mid Pleistocene (Agri valley fault system in Cello et al. 1989; Cello et al. 2000) dismembered the pile of tectonic units that make up the axial sector of the Apennine chain. This allowed the exhumation of the deeper tectonic units, which are visible in the slopes of the sides of the valley.

The presence of NW-SE trending faults, nearly parallel to the average orientation of the Agri valley, can be deduced from the morphology of the 'Il Monte' carbonate block, which displays a typical staircase structure. These faults are the result of the recent tectonics that has affected the axial sector of the Southern Apennines since the Middle Pleistocene (Giano et al. 2000). In more detail, 'Il Monte' is bounded by a series of normal faults, oriented approximately $\mathrm{N} 30^{\circ} \mathrm{E}$, controlling the

Fig. 8 Geological map of the "Il

Monte" area

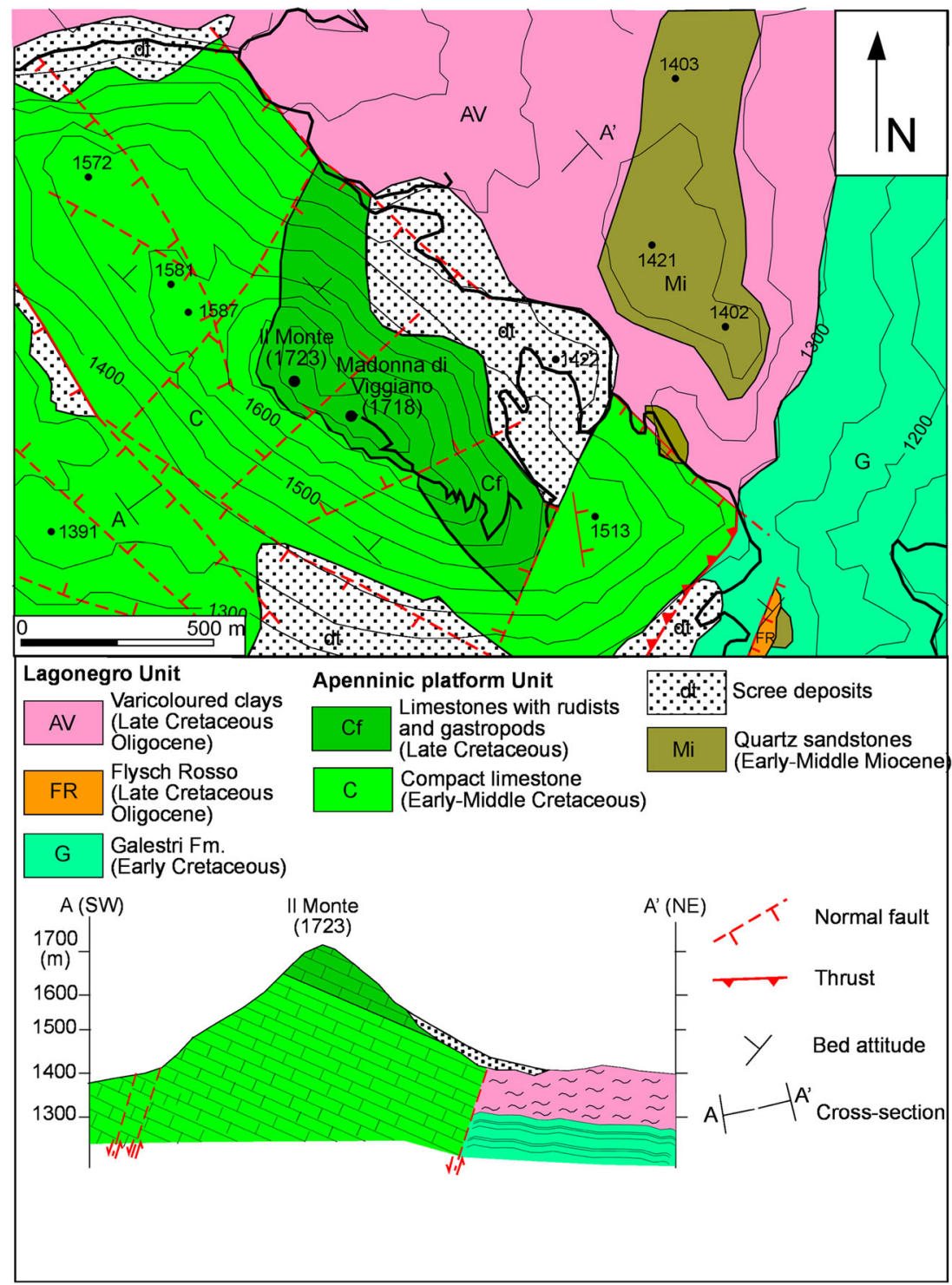


northern and southern slopes, and by a series of left-lateral strike-slip and normal faults oriented N120-160 that affect the morphology of the eastern and western sides.

The presence of a $\mathrm{N} 30^{\circ} \mathrm{E}$ trending graben along the northwestern side of the 'Il Monte' (Bucci et al. 2012, 2014) allows the inspection of the chronological relationships between the two main fault sets. In particular, at this locality, a $\mathrm{N} 160^{\circ} \mathrm{E}$ trending fault, showing a left-lateral component can be seen to crosscut a N30 ${ }^{\circ} \mathrm{E}$-oriented fault connected to the formation of the graben. In addition, $\mathrm{N} 160^{\circ} \mathrm{E}$ trending faults crosscut cemented slope deposits referred to the Early-Middle Pleistocene (Giano et al. 2000). This indicates that Pleistocene $\mathrm{N} 160^{\circ} \mathrm{E}$ trending faults, possibly connected to the formation of the Agri valley, formed after the minor $\mathrm{N} 30^{\circ} \mathrm{E}$ trending graben.

The stratigraphic succession of 'Il Monte' consists essentially of two stratigraphic intervals, of Jurassic and Cretaceous ages, respectively, related to carbonate platform and fore-reef environments (Fig. 9a) (Lechler 2011; Cestari and Laviano 2012). The lower interval is represented by a dense alternation of well-stratified oolitic limestones and limestones of the Lower Jurassic age, containing foraminifera and bivalves (Fig. 9b, c) and frequently associated with Lithiotis limestones. The latter are large bivalves, which can reach a size between 15 and $20 \mathrm{~cm}$ in diameter, which colonized the Mesozoic sea floor. The upper interval is represented by structureless limestones containing large quantities of rudist fragments and gastropods of Cenomanian age (Upper Cretaceous; Figs. 9d, e). Among the rudists, radiolitid and caprinid bioclasts have very commonly been recognized.

Along the trail that leads to the top of 'Il Monte' and the Sanctuary of the 'Madonna di Viggiano', it is possible to inspect a continuous succession of the upper interval. At the base of the trail, outcrops of limestone containing large rudists are well exposed. These mostly consist of caprinid clusters, isolated within the bioclastic carbonate sediment, which are sometimes preserved in life position. In some cases, it is possible to observe complete shells isolated from the carbonate matrix and ranging from a few centimetres to decimetres in size. In many cases, internal structures such as channels typical of the Caprinidae are clearly visible. Rarely, rudists preserve both valves. Bioclastic rudstones, consisting of entire or fragmented shells resulting from the erosion of underlying deposits, often follow above. Well-preserved coral colonies are locally found, together with spectacular specimens of Nerineid gastropods. This stratigraphic sequence is frequently interrupted by minor faults.
Fig. 9 a Panoramic view of the 'Il Monte'. b Microphotographs showing oolitic limestones and foraminifera-rich bioclastic limestones; c Lower Jurassic Lithiotis limestones; $\mathbf{d}$ rudist limestones with radiolitids and caprinids; e limestones with gastropods

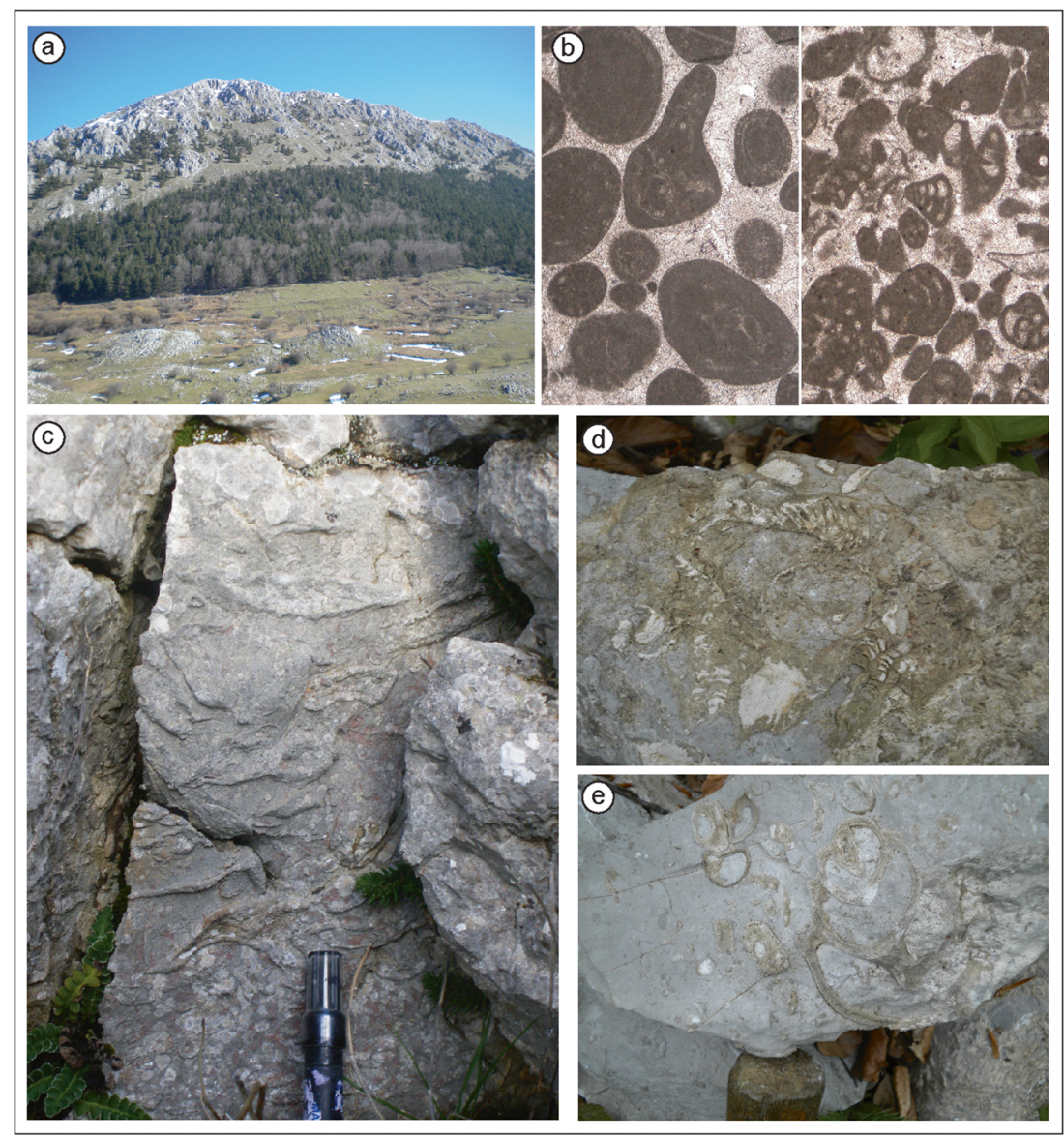




\section{Stop 5-the Monte Volturino Structure}

From the Eocene onwards (Knott 1994). the palaeogeographic domains forming the present-day Southern Apennine thrust belt experienced contractional deformation related to the subduction of the Tethys Ocean and the interaction between the European and African plates (Monaco et al. 1998). According to Mazzoli et al. (2001) and Patacca and Scandone (2007). thrust propagation was locally preceded and accompanied by buckling of the rheologically more competent stratigraphic units embedded between less competent shaly and marly units. Development of kink and box folds at both regional to local scales can be related to this shortening episode. The most remarkable folds are exposed along the left flank of the Agri River and Melandro valleys (Bucci et al. 2012, 2014). Among these, the Monte Volturino structure consists of a N10 trending anticline-syncline pair involving the Mesozoic, thinly bedded, deep-water Lagonegro deposits, as represented by the Calcari con Selce, Scisti Silicei and Galestri formations (Scandone 1967, 1972) (Figs. 10 and 11).
The synclinal axial plane dips about $45-50^{\circ}$ towards the W. The fold is affected by weak undulations that determine local plunge variations, ranging between $12^{\circ}$ and $20^{\circ}$ towards the $\mathrm{S}$ or the N (Fig. 11a). The origin of the fold is linked to the buckling of a multilayer succession, consisting mainly of competent limestone and chert, with thinly bedded shale intercalations (Calcari con Selce and Scisti Silicei formations). The occurrence of shale and marl of the Lower Cretaceous Galestri Formation above this relatively competent multilayer further facilitated the buckling process.

The multilayer was deformed during the Miocene, during the mountain-building processes of the Southern Apennines. The antiform shows a box-fold geometry characterized by a flat top linked to the adjacent syncline by an overturned eastern limb. The major fold is associated with different orders of well-exposed S-, M- and Z-shaped parasitic folds which are particularly well developed at the transition between the Calcari con Selce and Scisti Silicei formations (Fig. 11b-d, respectively). In addition, $\mathrm{M}$-shaped geometries can be clearly observed at the hinge of the Monte Volturino syncline. Orientation and asymmetry of parasitic folds are consistent

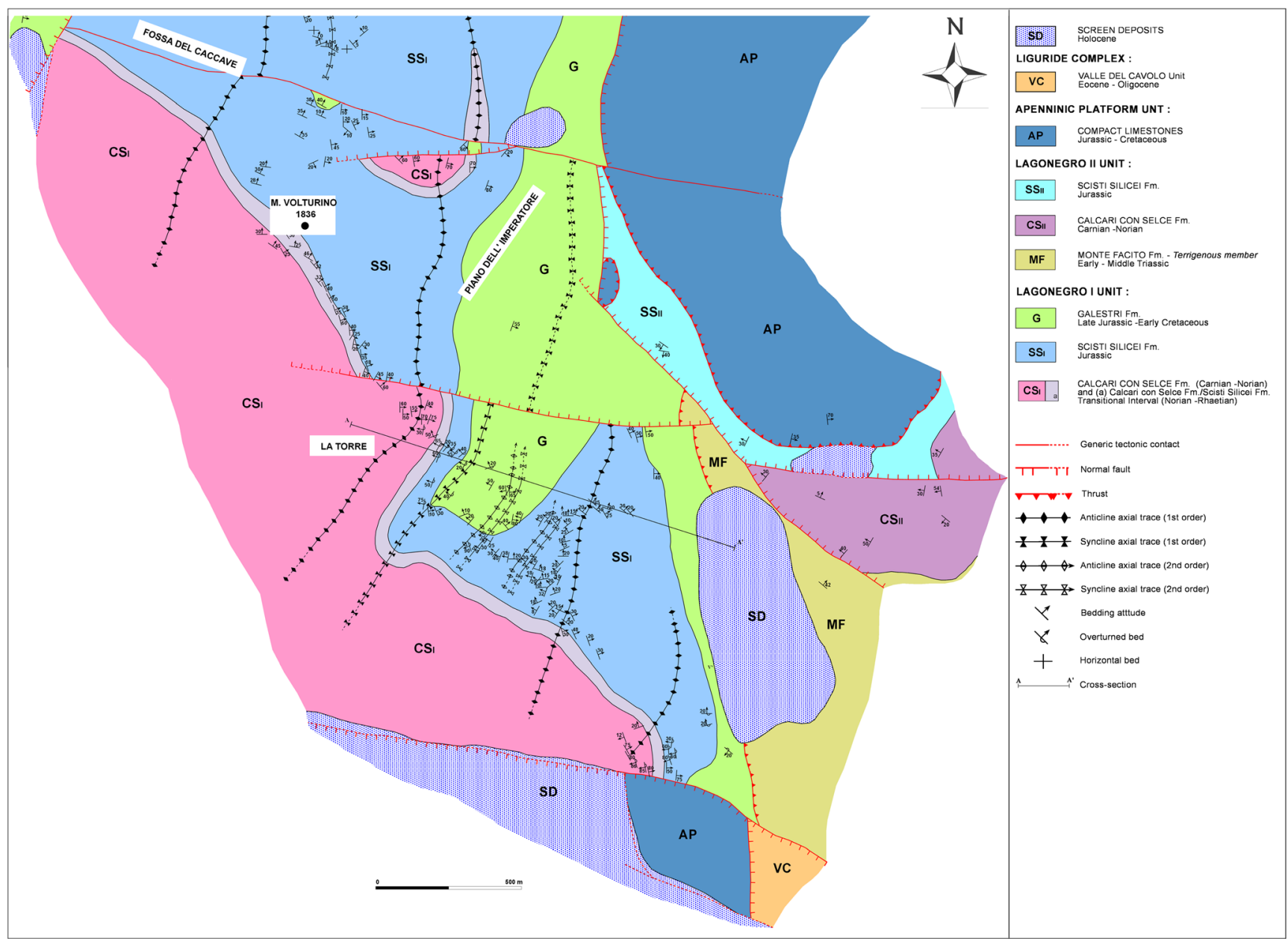

Fig. 10 Geological map of the Monte Volturino area 


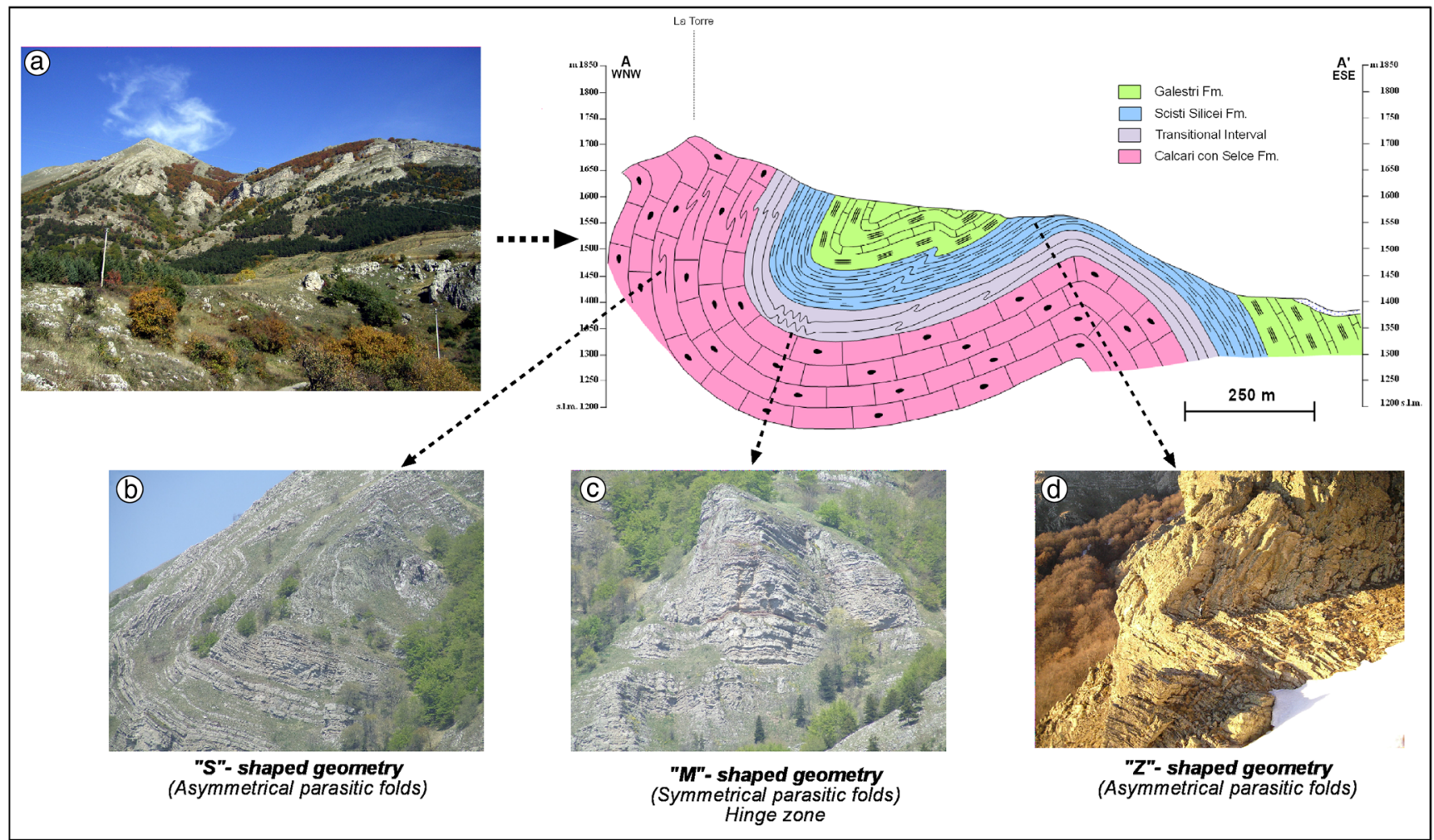

Fig. 11 Cross-section of the Monte Volturino folded multilayer. a Panoramic view of the M. Volturino syncline; $\mathbf{b}-\mathbf{d}$ parasitic fold distribution within the main structure is displayed

with trend, geometry and style of the host, large-scale fold. Although substantially preserved, the described fold is locally affected by more recent high-angle normal faults related to the Pleistocene extensional tectonics, responsible for the formation of the Agri valley graben. These faults are sometimes replaced to the south by left-lateral strike-slip faults, analogue to those described at the Lucania-Calabria boundary by Catalano et al. (1993).

\section{Stop 6-the Monte Lama-Serra di Calvello Structure}

The Monte Lama-Serra di Calvello structure consists of a more than 8-km long prominent N-trending box fold, with a marked plunge to the $\mathrm{N}$, involving the Mesozoic Lagonegro Basin deposits (Scandone 1972; Mazzoli et al. 2001) (Fig. 12). These latter consist of a multilayer made up of limestone, chert and marl of the Calcari con Selce (Upper Triassic), Scisti Silicei (Jurassic) and Galestri (Cretaceous) formations.

The structure is characterized by a vertical western limb and a steep to overturned eastern limb, offset by minor thrusts. The presence of basal thrusts with double vergence indicates a pop-up structure, as commonly recognized in fold-and-thrust belts. A series of extensional faults, cross-cutting the Monte Lama-Serra di Calvello fold, interrupts its lateral continuity favouring, at the same time, the complete exposure of natural sections oriented, in many cases, orthogonally to the fold axis.
This is the case on the southern side of the Monte Lama crest, where the core of the Monte Lama-Serra di Calvello structure is completely exposed for many hundreds of metres (Fig. 13). Here, the stratigraphy includes also a basal Carnian level (the Sorgente Acero Member according to Patacca and Scandone 2007). mainly made up of clay and limestone. This unit is characterized by intense cleavage and widespread calcite veins since it represents the detachment level that allowed buckling of the overlying Late Triassic-Cretaceous strata.

Looking at the west side of Serra di Calvello crest, it is possible to observe a series of pentagonal facets, modelled in the Calcari con Selce, giving rise to a very impressive morphology. These morphologies have been considered to represent remarkable examples of 'flat irons' (Bucci et al. 2007). developed upon inclined beds of the Monte LamaSerra di Calvello structure (Bentivenga et al. 2012) (Fig. 13b).

\section{Stop 7-Structures at Sasso di Castalda}

In the Sasso di Castalda area, both contractional and extensional structures, responsible for the present tectonic setting of the Southern Apennine thrust belt, are exposed in spectacular outcrops (Palladino et al. 2013). In particular, meso- and largescale thrusts, folds and faults are clearly exposed along the La Manca gorge (Fig. 14). At this locality, the southwestern limb 


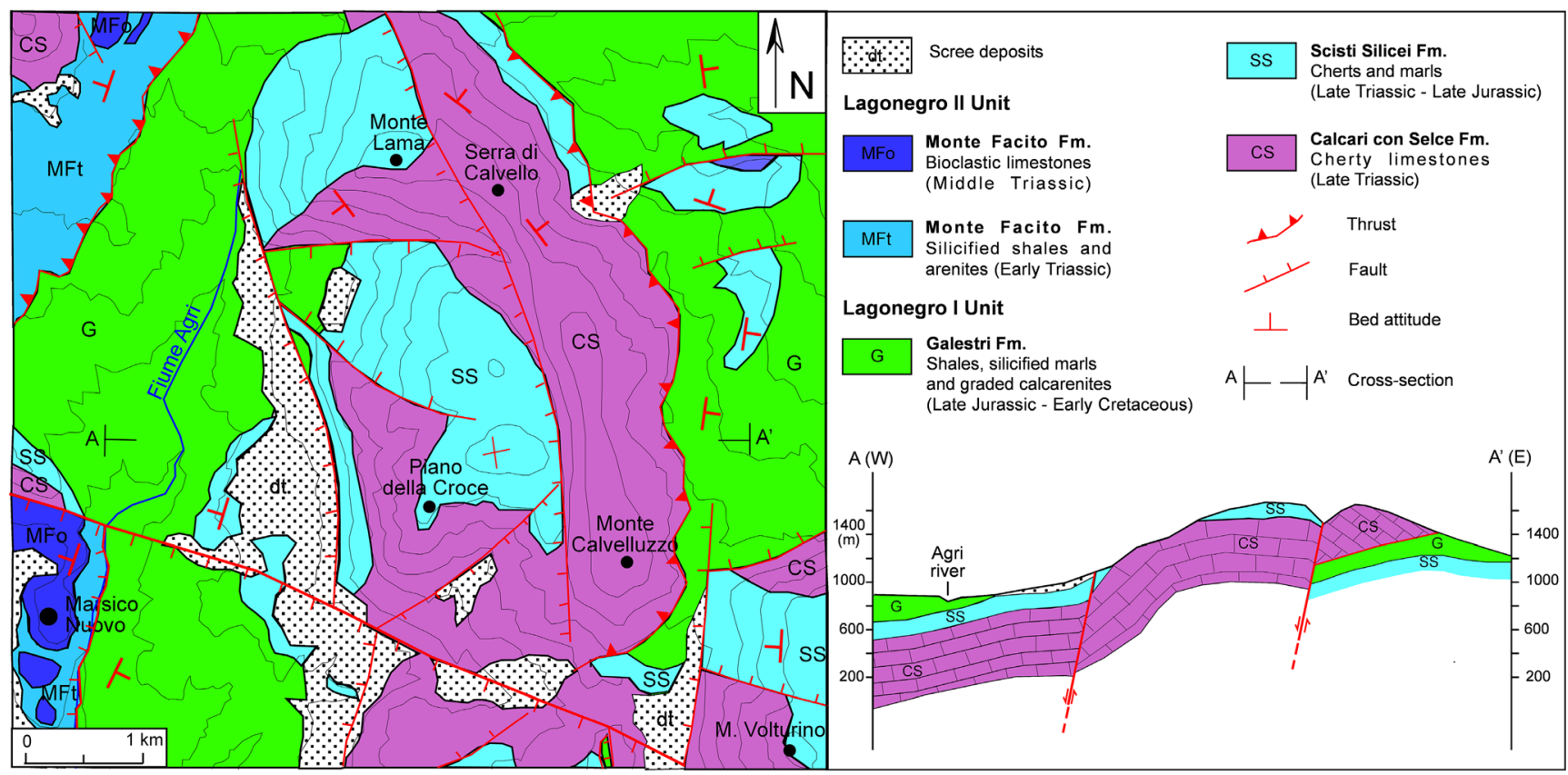

Fig. 12 Geological map of the Monte Lama and Serra di Calvello area

of a kilometre-scale box fold, here identified as La Manca fold, can be observed in detail (Fig. 15a).

The two hinge lines of the box fold are oriented around NW-SE showing a gentle plunge towards NW. In the southwestern limb, the dip angle of the bedding planes changes from just a few degrees to around $70^{\circ}$, showing a welldeveloped kink geometry. At a smaller scale, a series of parasitic folds, showing an asymmetry consistent with the main anticline, develops along the fold limbs. Parasitic folds may be associated to low-angle, outcrop-scale thrusts. Other outcropscale kink folds located at the base of 'Il Castello' cliff and Buccaglione Hill are probably unrelated to the development of the main anticline.

Bedding planes in the limestones of the Calcari con Selce formation, exposed at the hinge zones of the box fold, are frequently stylolitized. Often, a series of calcite steps, consistent with folding by flexural slip processes, have been recognized on the strata surfaces. In the area of Sasso di Castalda, the contractional structures are largely dissected by younger faults. In particular, a prominent NNE-SSW-oriented oblique dextral-normal (transtensional) fault cuts the previously described box fold, interrupting its lateral SE continuity. This structure, here identified as the Arenatra fault, offsets the Scisti Silicei/Galestri boundary with a throw of about $100 \mathrm{~m}$ (Fig. 15b).

A series of shear sense indicators, well visible at the outcrop scale, can be used to obtain the kinematics of the fault plane. These structures can be easily recognized on the main slip surface and in the fault damage zone. The most evident kinematic indicators are represented by oblique slickensides. In addition, the Calcari con Selce formation strata at the footwall are dragged along the fault plane assuming an antiform geometry, in agreement with a dextral-normal oblique-slip kinematics. Coherently, a series of en-echelon tension gashes, clearly related to the dextral slip component of the fault, can be observed in the vicinity of the fault plane. The fault has visible effects on the landscape, since part of the Arenatra stream follows its trend.

Sasso of Castalda is an excellent example of the recognition of an area with a strong geological interest. Here, a
Fig. 13 a Panoramic view of the Monte Lama structure; b Serra di Calvello 'flat-iron's from Marsico Nuovo village

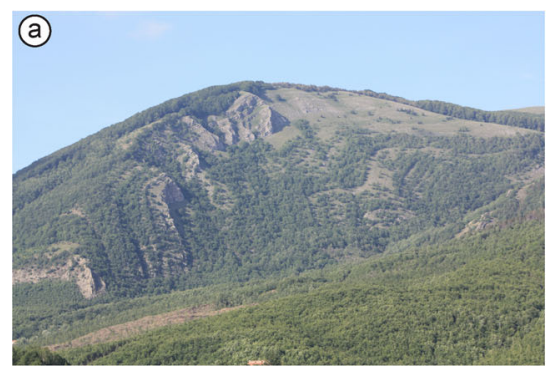

(b)

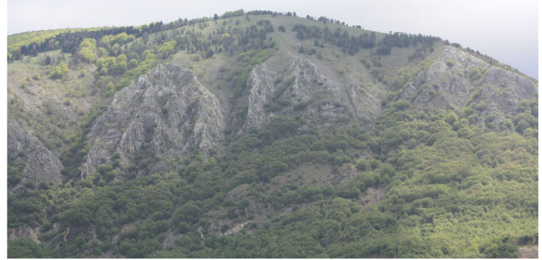




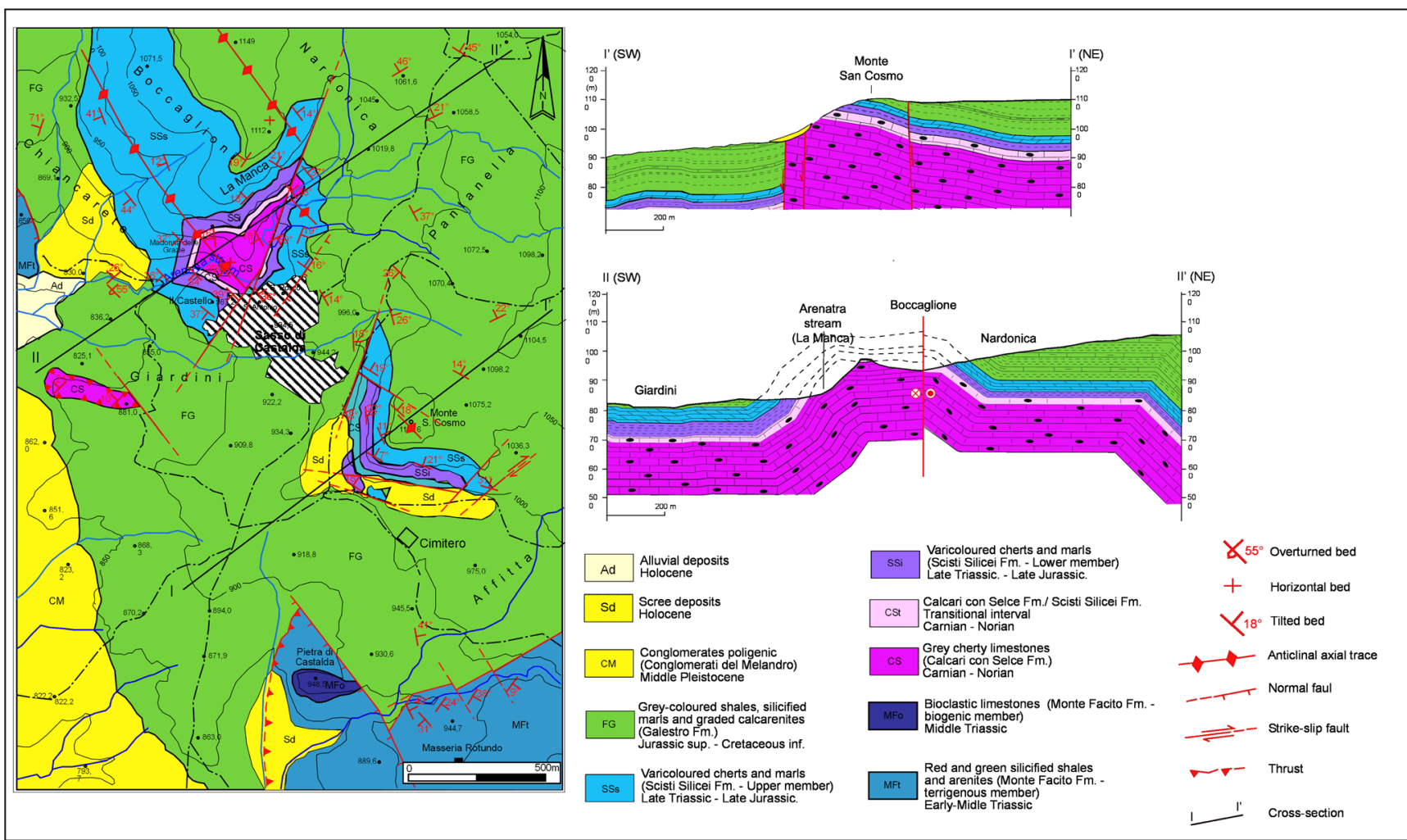

Fig. 14 Geological map of the Sasso di Castalda area

proposed geological itinerary is mainly developed in the urban area (Palladino et al. 2013). The itinerary is designed to present to an audience of non-experts and experts, a journey through geological time by observing the oldest rocks of the Southern Apennines. Because of the high educational content, the itinerary has been chosen as a destination by many schools, of different levels, and numerous Italian and foreign universities.

\section{Conclusions}

The itinerary described in this paper connects seven sites of great geological interest distributed between the front and the inner portions of the Southern Apennine thrust belt. The stops, each of them representing individual geosites, have been selected as they all show a common leitmotif: the presence of clear stratigraphical, structural and geomorphological features useful for understanding the complex multiphase history of the chain.

Among the illustrated geosites, only a few have implemented geoconservation measures, for instance, those that fall within the territory of the National Park of the Appennino Lucano-Val d'Agri-Lagonegrese (Monte Lama and Serra di Calvello, Monte Volturino and Il Monte) (Henriques 2010; Henriques et al. 2011; Geremia et al. 2015). The Sasso di Castalda structure is the only one which, currently, benefits from partial protection and geoconservation procedures provided by the local administration. In contrast, the most sensitive site appears to be Craco village, which is presently semi-
Fig. 15 a Panorama view of the La Manca fold from the Sasso di Castalda village; $\mathbf{b}$ view of the Arenatra Fault, which offset the La Manca fold in the correspondence of the Sasso di Castalda village
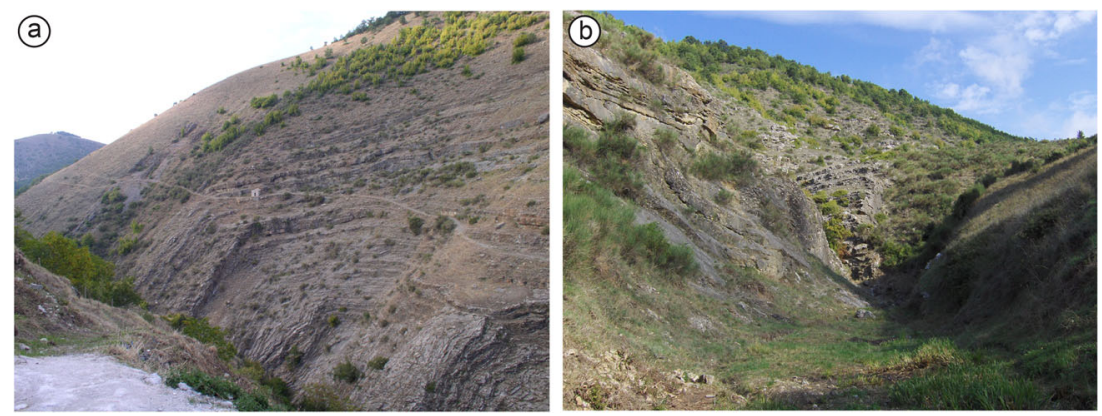
abandoned and needs immediate and suitable conservation actions (although the municipal administration here has planned to set up a praesidium to prevent people entering between the unsafe houses and to prevent further looting).

It is believed that the development of the geological itinerary could strongly contribute to spreading knowledge of the geological heritage of the Basilicata Region. The proposed itinerary has been established based not only on the presence of sites of great scientific interest but also on the beauty of the landscape of the whole area. A more disseminated knowledge of this itinerary will encourage planning authorities to pay more attention and to prepare actions for geoconservation and the development of geotourism (Hose 2000). and, hence, in a short time, geoconservation procedures for all the described geosites will be set up. This may also happen through public initiatives aimed at increasing a consciousness about the richness of this geological heritage within the local population. In addition, protection of the described geosites, and in general of the geological heritage of the whole Basilicata, would be possible through the introduction of a specific regional law, similar to those that have been already established in some other Italian regions.

The proposal of this itinerary is aimed at creating an opportunity to raise awareness of the geological features present in the different domains of the Southern Apennines which need to be protected and promoted. In particular, it has been demonstrated that the most degradated geosites are represented by Craco village and the Aliano badland area. It is hoped that, in the short term, land managers will undertake management activities for their geoconservation and promotion.

Open Access This article is distributed under the terms of the Creative Commons Attribution 4.0 International License (http:// creativecommons.org/licenses/by/4.0/), which permits unrestricted use, distribution, and reproduction in any medium, provided you give appropriate credit to the original author(s) and the source, provide a link to the Creative Commons license, and indicate if changes were made.

\section{References}

Balduzzi A, Casnedi R, Crescenti U, Mostardini F, Tonna M (1982) Il Plio-Pleistocene del sottosuolo nel bacino lucano (Avanfossa appenninica). Geol Romana 21:1-28

Bentivenga M, Coltorti M, Prosser G, Tavarnelli E (2004) A new interpretation of terraces in the Taranto Gulf: the role of extensional faulting. Geomorphology 60:383-402

Bentivenga M, Palladino G, Caputi A (2012) Development of the Pietra Maura landslide and interactions with the Marsico Nuovo dam (Basilicata-Italy). Geografia Fisica e Dinamica del Quaternario 35:13-22. doi:10.4461/GFDQ.2012.35.2

Bentivenga M, Foresi ML, Prestera A, Prosser G, Sabia M (2005) Structural setting at the front of a thrust and fold belt: the Craco area (Southern Apennines, Italy). Bol. Soc Geol It 124:367-376
Bentivenga M, Fascetti S (1999) Le aree calanchive della Basilicata: aspetti geomorfologici e geobotanici. Biologi Italiani $\mathrm{n}^{\circ} 5$ maggio $5: 16-24$

Benvenuti M, Bonini M, Moratti G, Sani F (2006) Tectonosedimentary evolution of the Plio-Pleistocene Sant'Arcangelo Basin (Southern Apennines, (Italy) - In: Moratti, G. \& Chalouan, A. (eds.), Tectonics of the Western Mediterranean and North Africa. Geol Soc London Spec Publ 262:289-322

Bigazzi G, Bonadonna FP (1988) Fission track dating of a volcanic ash layer near Pisticci (Basilicata, Italy). Il Quaternario Italian Journal of Quaternary Sciences 1(2):127-129

Bigi G, Cosentino D, Parotto M, Santori R \& Scandone P (1991) Structural model of Italy (sheet 6), scala 1:500.000. (Quaderni de «La Ricerca Scientifica», 114, 3), Consiglio Nazionale delle Ricerche, Progetto Finalizzato Geodinamica, Sottoprogetto Modello strutturale tridimensionale.

Bonardi G, Ciampo G, Perrone V (1985) La formazione di Albidona nell'Appennino calabro-lucano: ulteriori dati stratigrafici e relazioni con le unità esterne appenniniche. Bollettino Della Società Geologica Italiana 104:539-549

Bonini M, Sani F (2000) Pliocene-Quaternary transpressional evolution of the Anzi-Calvello and northern S. Arcangelo basins (Basilicata, Southern Apennines, Italy) as a consequence of deep-seated fault reactivation. Mar Pet Geol 17:909-927

Bucci F, Novellino R, Guglielmi P, Prosser G, Tavarnelli E (2012) Geological map of the northeastern sector of the high Agri valley, Southern Apennines (Basilicata, Italy). Journal of Maps. doi:10. 1080/17445647.2012.722403

Bucci F, Novellino R, Tavarnelli E, Prosser G, Guzzetti F, Cardinali M, Gueguen E, Guglielmi P \& Adurno I (2014) Frontal collapse during thrust propagation in mountain belts: a case study in the Lucania Apennines, Southern Italy. Journal of the Geological Society, London. http://dx.doi.org/10.1144/jgs2013-103

Bucci F, D'Onofrio D, Tavarnelli E \& Prosser G (2007) Triangular facets or flatirons? A note of caution from the Lucanian Apennines, Italy. Rend Soc Geol It 5, Nuova Serie, 91.

Caldara M, Loiacono F, Morlotti E, Pieri P, Sabato L (1988) I depositi Plio-Pleistocenici della parte Nord del Bacino di S. Arcangelo (Appennino Lucano): caratteri geologici e paleoambientali. Mem Soc Geol It 41:391-410

Carannante G, Graziano R, Pappone G, Ruberti D, Simone L (1999) Depositional system and response to sea level oscillations of the sennonian rudist-bearing carbonate shelves. Examples from central Mediterranean areas. Facies 40:1-24

Carbone S, Catalano S, Lazzari S, Lentini F, Monaco C (1991) Presentazione della Carta Geologica del Fiume Agri (Basilicata). Memorie della Società Geologica Italiana 47:129-143

Casero P, Roure F, Endignoux L, Moretti I, Muller C, Sage L, Vially R (1988) Neogene geodinamic evolution of the Southern Apennines. Memorie della Società Geologica Italiana 41:109-120

Cavalcante F, Belviso C, Laurita S, Prosser G (2012) P-T constraints from phyllosilicates of the Liguride Complex of the Pollino area (Southern Apennines, Italy): geological inferences. Ofioliti 37:6575

Catalano S, Monaco C, Tortorici L, Tansi C (1993) Pleistocene strike-slip tectonics in the Lucanian Apennine (Southern Italy). Tectonics 12: 656-665

Cello G, Martini N, Paltrinieri W, Tortorici L (1989) Structural styles in the frontal zones of the Southern Apennines, Italy: an example from the Molise district. Tectonics 8(4):753-768

Cello G, Mazzoli S (1999) Apennine tectonics in Southern Italy: a review. J Geodyn 16:191-211

Cello G, Gambini R, Mazzoli S, Read A, Tondi E, Zucconi V (2000) The Val d'Agri fault system. In: Cello, G., Tondi, E. (Eds), The resolution of geological analysis and models for earthquake faulting studies. J Geodyn 29(3-5):293-308 
Cestari R \& Laviano A (2012) Rudist facies distribution in the Late Cretaceous of Cilento and western Basilicata (Southern Italy). Proceedings of the Palermo workshop "New developments on Triassic integrated stratigraphy", 12-13 September 2010

Crescenti U (1975) Sul substrato pre-pliocenico dell'avanfossa appenninica dalle Marche allo Jonio. Bollettino della Società Geologica Italiana 94:583-634

D'Argenio B, Pescatore T, Scandone P (1973) Schema geologico dell'Appennino Meridionale. Atti del convegno "Moderne vedute sulla geologia dell'Appennino". Accademia Nazionale dei Lincei Quaderno 183:49-72

Del Prete M, Bentivenga M, Coppola L, Rendell H (1994) Aspetti evolutivi dei reticoli calanchivi a sud di Pisticci. Geologica Romana 30:295-306 Roma

Doglioni C (1991) A proposal of kinematic modelling for W-dipping subductions - possible applications to the Tyrrhenian-Apennines system. Terra Nov. 3:423-434

Foresi LM, Mazzei R \& Salvatorini G (2000-2001) Appendice biocronostratigrafica. In: Bossio A. \& alii - Note illustrative alla carta geologica della zona di S. Maria di Leuca. Atti Soc Tosc Sci Nat Mem Serie A 106:97-163

Geremia F, Bentivenga M \& Palladino G (2015) Environmental geology applied to geoconservation in the interaction between geosites and linear infrastructures in south-eastern Italy. Geoheritage. doi:10. 1007/s12371-015-0146-Z

Giano SI, Maschio L, Alessio M, Ferranti L, Improta S, Schiattarella M (2000) Radiocarbon dating active faulting in the Agri high valley, southern Italy. J Geodyn 29:371-386

Gueguen E, Doglioni C, Fernandez M (1998) On the post-25 Ma geodynamic evolution of western Mediterranean. Tectonophysics 298:259-269

Henriques MH (2010) O Ano Internacional do Planeta Terra e a Educação para a Geoconservação. In: Cotelo Neiva JM, Ribeiro A, Mendes Victor L, Noronha F, Magalhães Ramalho M (eds) Livro Branco da Geologia de Portugal, vol II (IV). Assoc Portu- guesa de Geólogos and Soc Geol Portugal, Lisboa, pp. 465-474

Henriques MH, Reis RP, Brilha J, Mota T (2011) Geoconservation as an emerging geoscience. Geoheritage 3:117-128. doi:10.1007/ s12371-011-0039-8

Hippolyte JC, Angelier J, Roure F, Casero P (1994) Piggy-back basin development and thrust belt evolution: structural and paleostress analyses of Plio-Quaternary basins in the Southern Apennines. J Struct Geol 16:159-173

Hose TA (2000) European geoturism-geological interpretation and geoconservation promotion for tourists. In: Barretino D, Wimbledon WP, Gallego E (eds) Geologica heritage: its conservation and managenment. Instituto Tecnologico Geominero de Espana, Madrid, pp. 127-146

Iaccarino S, Salvatorini G (1982) A framework of planktonic foraminifera biostratigraphy for Early Miocene to Late Pliocene Mediterranean area. Pal Strat Evol 2:115-125

Iannace A, Parente M, Zamparelli V (2005) The Upper Triassic platform margin facies of Southern Apennines and their Jurassic fate: state of the art. Boll Soc Geol It 124:203-214

Invernizzi C, Bigazzi G, Corrado S, Di Leo P, Schiattarella M, Zattin M (2008) New thermobaric constraints on the exhumation history of the Liguride accretionary wedge, southern Italy. Ofioliti 33:21-32

Kastens K, Mascle J, ODP Leg 107 scientific party (1988) ODP Leg in the Tyrrhenian Sea: insights into passive margin and back-arc basin evolution. Geol Soc Am Bull 100:1140-1156

Knott SD (1994) Structure, kinematics and metamorphism in the Liguride Complex, Southern Apennines Italy. J Struct Geol 16:1107-1120

Lazzari S, Lentini F (1980) Note illustrative del F.507 Pisticci. Regione Basilicata Potenza 1:1-55

Lechler M (2011) Stratigraphic setting of the eastern margin of the Apennine platform (Southern Apennines, Basilicata): a clue to understand the Mesozoic platform to basin transition in the southern Tethyan domain. Universität Potsdam, Institut für Erd- und Umweltwissenschaften in Collaboration with Università degli Studi della Basilicata, Dipartimento di Scienze Geologiche, Diploma Thesis

Lentini F, Carbone S, Di Stefano A, Guarnieri P (2002) Stratigraphical and structural constraints in the Lucanian Apennines (southern Italy): tools for reconstructing the geological evolution. J Geodyn 34:141-158

Lentini F, Carbone S, Catalano S, Monaco C (1987) Confronti sedimentologico-petrografici e posizione strutturale dei Flysch di Albidona e di Gorgoglione nella media Val d'Agri (Appennino Lucano). Mem Soc Geol It 38:259-273

Lentini F (1979) Le Unità Sicilidi della Val d'Agri (Appennino Lucano). Geol Romana 8:215-225

Malinverno A, Ryan WBF (1986) Extension in the Tyrrhenian Sea and shortening in the Apennines as a result of arc migration driven by sinking of the lithosphere. Tectonics 5:227-245

Marsella E, Pappone G (1987) Sediment gravity flows on a Mesozoic carbonate slope. Monti della Maddalena (Southern Apennines). Rend Soc Geol It 9:219-224

Mattei M, Cifelli F, D'Agostino N (2007) The evolution of the Calabrian arc: evidence from paleomagnetic and GPS observations. Earth Planet Sci Lett. doi:10.1016/j.epsl.2007.08.034

Mazzoli S, Barkham S, Cello G, Gambini R, Mattioni L, Shiner P, Tondi E (2001) Reconstruction of continental margin architecture deformed by the contraction of the Lagonegro Basin, Southern Apennines, Italy. J Geol Soc 158:309-319

Menardi Noguera A, Rea G (2000) Deep structure of the CampanianLucanian Arc (Southern Apennine, Italy). Tectonophysics 324:239 265

Monaco C, Tortorici L (1995) Tectonic role of ophiolite-bearing terranes in the development of the Southern Apennines orogenic belt. Terra Nov. 7:153-160

Monaco C, Tortorici L, Paltrinieri W (1998) Structural evolution of the lucanian Apennines, southern Italy. J Struct Geol 20:617-638

Mostardini F \& Merlini S (1986) Appennino centro meridionale. Sezioni geologiche e proposta di modello strutturale. Memorie della Società Geologica Italiana 35:177-202

Nicolai C, Gambini R (2007) Structural architecture of the "Adria platform-and-basin System". Bollettino della Società Geologica Italiana Volume Speciale 7:453-763

Ogniben L (1969) Schema introduttivo alla geologia del confine calabrolucano. Memorie della Società Geologica Italiana 8:453-763

Palladino G (2011) Tectonic and eustatic controls on Pliocene accommodation space along the front of the southern Apennine thrust-belt (Basilicata, southern Italy). Basin Res 23:591-612

Palladino G, Prosser G, Bentivenga M (2013) The geological itinerary of Sasso di Castalda: a journey into the geological history of the southern Apennine thrust-belt (Basilicata-southern Italy). Geoheritage. doi:10.1007/s12371-012-0073-1

Patacca E \& Scandone P (2001) Late thrust propagation and sedimentary response in the thrust-belt-foredeep system of the Southern Apennines (Pliocene-Pleistocene). In G. B. Vai \& I. P. Martini (eds). Anatomy of an Orogen: the Apennines and Adjacent Mediterranean Basins, Kluwer Academic Publishers, 401-440.

Patacca E \& Scandone P (2007) Geology of the Southern Apennines. Boll. Soc. Geol. It., Spec. Issue No. 7 (2007), 75-119, CROP-04 (ed. by A. Mazzotti, E. Patacca \& P. Scandone).

Pescatore T (1988) La sedimentazione miocenica nell'Appennino Campano-Lucano. Mem Soc Geol It 41:37-46

Pescatore T, Renda P, Schiattarella M, Tramutoli M (1999) Stratigraphic and structural relationships between Meso-Cenozoic Lagonegro basin and coeval carbonate platforms in Southern Apennines, Italy. Tectonophysics 315:269-286 
Piccarreta M, Faulkner H, Bentivenga M, Capolongo D (2006a) The influence of physico-chemical material properties on erosion processes in the badlands of Basilicata, southern Italy. Geomorphology $81: 235-251$

Piccarreta M, Capolongo D, Boenzi F, Bentivenga M (2006b) Implications of decadal changes in precipitation and land use policy to soil erosion in Basilicata, Italy. Catena 65:138-151

Piccarreta M, Capolongo D, Miccoli MN, Bentivenga M (2012) Global change and long-term gully sediment production dynamics in Basilicata, southern Italy. Environ Earth Sci. doi:10.1007/s12665012-1603-5

Piedilato S, Prosser G (2005) Thrust sequences and evolution of the external sector of a fold and thrust belt: an example from the Southern Apennines (Italy). J Geodyn 39:386-402

Pieri P, Vitale G, Beneduce P, Doglioni C, Gallicchio S, Giano SI, Loizzo R, Moretti M, Prosser G, Sabato L, Schiattarella M, Tramutoli M, Tropeano M (1997) Tettonica quaternaria nell'area bradanicoionica. Il Quaternario 10:535-542

Pieri P, Sabato L, Loiacono F, Marino M (1994) Il bacino piggyback di Sant'Arcangelo: evoluzione tettonico-sedimentaria. Boll Soc Geol It 113:465-481

Prosser G, Bentivenga M, Laurenzi M, Caggianelli A, Dellino P, Doronzo D (2008) Late Pliocene volcaniclastic products from Southern Apennines: distal witness of early explosive volcanism in central Tyrrhenian Sea. Geol Mag. doi:10.1017/ S0016756808004512

Ricchetti G, Ciaranfi N, Luperto Sinni E, Mongelli F, Pieri P (1988) Geodinamica ed evoluzione sedimentaria e tettonica dell'Avampaese Apulo. Memorie della Società Geologica Italiana 41:57-82

Rosenbaum G \& Lister GS (2004) Neogene and Quaternary rollback evolution of the Tyrrhenian Sea, the Apennines, and the Sicilian Maghrebides. Tectonics 23(1). doi:10.1029/2003TC001518
Roure F, Casero P, Vially R (1991) Growth processes and melanges formation in the Southern Apennines accretionary wedge. Earth Planet Sci Lett 102:395-412

Scandone P (1967) Studi di geologia lucana: la serie calcareo-silicomarnosa e i suoi rapporti con l'Appennino calcareo. Bollettino Società Naturalistica in Napoli 6:1-175

Scandone P, Bonardi G (1968) Synsedimentary tectonics controlling deposition of mesozoic and tertiary carbonatic sequences of areas surrounding Vallo di Diano (southern Apennines). Mem Soc Geol It 7:1-10

Scandone P (1972) Studi di geologia Lucana: carta dei terreni della serie calcareo-silico-marnosa e note illustrative. Bollettino della Società dei Naturalisti in Napoli 70:114-299

Sella M, Turci C, Riva A (1988) Sintesi geopetrolifera della Fossa Bradanica (Avanfossa della catena appenninica Meridionale). Memorie della Società Geologica Italiana 41:87-107

Stampfli GM, Borel GD, Marchant R, Mosar J (2002) Western Alps geological constraints on western Tethyan reconstructions. J Virtual Explor 8:77-106

Van Dijk JP, Bello M, Brancaleoni GP, Cantarella G, Costa V, Frixia A, Golfetto F, Merlini S, Riva M, Torricelli S, Toscano C, Zerilli A (2000) A regional structural model for the northern sector of Calabrian Arc (southern Italy). Tectonophysics 324:267-320

Wimbledon WAP, Benton MJ, Bevins RE, Black GP, Bridgland DR, Cleal CJ, Cooper RG, May VJ (1995) The development of a methodology for the selection of British sites for conservation. Part 1. Modern Geology 20:159-202

Wimbledon WAP (1996a) National site selection, a stop on the way to a European Geosite list. Proceedings of the special symposium "Geological Heritage in South-East Europe", May 1995. Geological Balcanica 26:15-27

Wimbledon WAP (1996b) Geosites - a new conservation initiative. Episodes 19:87-88 